\title{
Low-dose interleukin-8 induces the adhesion, migration and invasion of the gastric cancer SGC-7901 cell line
}

\author{
JUN SHI and PIN-KANG WEI \\ Department of Traditional Chinese Medicine, Shanghai Changzheng Hospital, \\ The Second Military Medical University, Shanghai 200003, P.R. China \\ Received October 14, 2014; Accepted July 7, 2015
}

DOI: $10.3892 / \mathrm{ol} .2015 .3641$

\begin{abstract}
Interleukin-8 (IL-8), an important inflammatory cytokine, is strongly associated with gastric cancer development and metastasis. High-dose ( $>1 \mathrm{ng} / \mathrm{ml})$ IL- 8 has been revealed to promote the adhesion, migration and invasion of human gastric cancer SGC-7901 cells in a dose-dependent manner. However, the IL-8 level produced by gastric cells is marginal, at even less than $1 \mathrm{ng} / \mathrm{ml}$. It is unclear whether low-dose IL- 8 also induces these capacities. In the present study, the effect of low-dose IL- 8 on the adhesion, migration and invasion of the SGC-7901 cell line and the underlying molecular mechanism with regard to cluster of differentiation 44 (CD44) were investigated. The SGC-7901 cells were exposed to various concentrations of IL- $8(0,0.2,0.5,0.8$ and $1 \mathrm{ng} / \mathrm{ml}$ ) in vitro. The adhesion of the SGC-7901 cells to fibronectin, an extracellular matrix component, was then detected by cell counting kit 8 assay. Migration and invasion abilities were evaluated by wound scratch and Transwell chamber assays. In addition, protein and mRNA levels of CD44 were measured using immunofluorescence and western blotting, and quantitative polymerase chain reaction, respectively, in cells cultured for $72 \mathrm{~h}$. Following the exposure of the SGC-7901 cells to the various low doses of IL-8, the cell adhesion, migration and invasion capacities were promoted by IL-8, but not in a significant dose-dependent manner. Low-dose IL-8 upregulated the protein and mRNA expression of CD44. In conclusion, low-dose IL-8 potently induces the adhesion, migration and invasion of SGC-7901 cells, and the regulation of CD44 expression is one of the potential molecular mechanisms involved.
\end{abstract}

Correspondence to: Professor Pin-Kang Wei, Department of Traditional Chinese Medicine, Shanghai Changzheng Hospital, The Second Military Medical University, 415 Fengyang Road, Huangpu, Shanghai 200003, P.R. China

E-mail: czzyk73408@163.com

Key words: interleukin-8, gastric cancer, migration, adhesion, invasion, cluster of differentiation 44, gastric cancer SGC-7901 cell line

\section{Introduction}

The incidence of gastric cancer is gradually declining throughout the world, but it remains the second most common type of fatal malignancy worldwide (1). Gastric cancer is one of the most aggressive tumors due to its important pathological features of easy invasion and metastasis. The key steps of invasion and metastasis include dissociation from the primary lesions, degradation and permeation about the extracellular matrix (ECM), migration in the blood or lymph stream, and adhesion and growth within secondary organs (2). A number of pathways and genes have been indicated to be involved in the metastasis of gastric cancer. Previous studies have demonstrated that chemokines and their receptors function as essential regulators of metastatic cancers, including gastric cancer, and are involved in a number of neoplastic processes $(3,4)$.

Interleukin-8 (IL-8), a member of the neutrophil-specific CXC subfamily of chemokines with a Glu-Leu-Arg motif, is important in leukocyte chemotaxis, inflammatory responses and infectious diseases (5), as well as in the migration, invasion and proliferation of endothelial cells via their receptors, and in angiogenesis in vivo $(6,7)$. Previous studies have suggested that cancer cells, including those of pancreatic, colon, ovarian and lung cancer, produce IL-8 (8-15). IL-8, an autocrine growth factor, is associated with tumor growth, angiogenesis, invasion and metastasis (8-15). In our previous study, IL- 8 ranging from 0 to $100 \mathrm{ng} / \mathrm{ml}$ was shown to interfere with human gastric cancer SGC-7901 cells in vitro; it was found that high-dose IL-8 promoted cell adhesion to endothelial cell and ECM components, while also inducing the migration and invasion capacities of the SGC-7901 cells (16). However, the IL-8 level produced by gastric cells is marginal, at even less than $1 \mathrm{ng} / \mathrm{ml}$ (17). It remains unclear whether low-dose IL- 8 treatment also induces these capacities in cells.

The purpose of the present study was to provide direct information with regard to the role of low-dose IL-8 in determining the metastasis of gastric cancer. In the current study, IL-8 ranging from 0 to $1 \mathrm{ng} / \mathrm{ml}$ was used to interfere with the SGC-7901 cells in vitro to investigate the effect of low-dose IL-8 on the adhesion, migration and invasion capacities of the cells, and the correlated molecular mechanism of cluster of differentiation 44 (CD44). The present study was approved by 
the ethics committee of the Second Military Medical University (Shanghai, China).

\section{Materials and methods}

Cell culture. The human gastric cancer SGC-7901 cell line was purchased from the Cell Bank of the Type Culture Collection of the Chinese Academy of Sciences (Shanghai, China). The SGC-7901 cells were cultured in RPMI-1640 medium (Wisent, St. Bruno, Quebec, Canada) supplemented with $10 \%$ fetal bovine serum (Zhejiang Tianhang Biological Technology Co., Ltd., Hangzhou, China), $1 \%$ penicillin/streptomycin and $1 \%$ L-glutamine, and maintained at $37^{\circ} \mathrm{C}$ in a humidified chamber containing $5 \% \mathrm{CO}_{2}$.

Adhesion assay. Fibronectin is an ECM component. To analyze the attachment of the SGC-7901 cells to fibronectin, 96-well plates were coated with $100 \mu \mathrm{g}$ fibronectin (Sigma-Aldrich, St. Louis, MO, USA) overnight at $4^{\circ} \mathrm{C}$. Subsequent to being washed three times with phosphate-buffered saline (PBS) solution containing $1 \%$ bovine serum albumin (Sigma-Aldrich) to block non-specific cell adhesion, IL-8 $(0,0.2,0.5,0.8$ and $1.0 \mathrm{ng} / \mathrm{ml}$; Sigma-Aldrich) was added to $1 \times 10^{5}$ cells/well for $2 \mathrm{~h}$. Thereafter, the non-adherent cells were washed off with PBS. Cell adhesion was assessed by a cell counting kit 8 (Dojindo, Kunamoto, Japan) assay, using cellular DNA labeled with fluorescence reagent. The cells were cultured for an additional $4 \mathrm{~h}$. Colorimetric absorbance was measured by a microplate reader (Multiskan MK3; Thermo Fisher Scientific, Waltham, MA, USA) at $450 \mathrm{~nm}$ to obtain an optical density (OD) value. $\mathrm{OD}$ ultimate value $=\mathrm{OD}$ measured value $-\mathrm{OD}$ blank value.

Wound scratch assay. Cell migration was monitored in a wound scratch assay. Briefly, the SGC-7901 cells were seeded on a 6 -well plate at a density of $2 \times 10^{5}$ cells/well. A scratch was made with a sterile $10-\mu 1$ pipette tip in a confluent cell monolayer. Subsequent to washing twice, IL-8 (dose identical to adhesion assay) was added in serum-free medium. Images of the wells were captured at the beginning of the experiment and after 12 and $24 \mathrm{~h}$ on an inverted microscope (CK40-F200; Olympus, Tokyo, Japan). Digital images were obtained with an Optronics MicroFire digital camera (Optronics, Goleta, CA, USA) driven by the Picture Frame imaging software (Optronics). All experiments were repeated three times.

Transwell chamber invasion assay. Transwell chambers (Corning, Tewksbury, MA, USA) were used to examine the invasion ability of the SGC-7901 cells, according to the manufacturer's instructions. Briefly, the SGC-7901 cells $\left(8 \times 10^{4}\right)$ were seeded in the upper chamber consisting of a thin layer of Matrigel basement membrane matrix (BD Bioscience, San Jose, CA, USA). Next, $600 \mu 1$ culture medium and IL-8 (dose identical to adhesion assay) were added to the lower chamber. Subsequent to $24 \mathrm{~h}$ of incubation, the cells on the upper surface of the membrane were removed with a cotton swab, and the cells that had migrated through and attached to the lower surface of the membrane were fixed with $4 \%$ paraformaldehyde for $15 \mathrm{~min}$. Thereafter, the cells were stained using the crystal violet cell colony staining kit (Shanghai Genmed Biological Technology Co., Ltd., Shanghai, China) according to the manufacturer's instructions. The results are expressed as the mean number of cells invading in four random microscopic fields (magnification, $\mathrm{x} 10)$.

Immunofluorescence staining. A total of $2 \times 10^{5}$ SGC-7901 cells were seeded on 6-well plates and cultured with IL-8 (dose identical to adhesion assay) for $72 \mathrm{~h}$. Subsequently, $7 \times 10^{4}$ cells were placed on coverslips and fixed in $4 \%$ paraformaldehyde, permeabilized with $0.5 \%$ Triton X-100 (Shanghai Sangon Biotech Co., Ltd., Shanghai, China) for $10 \mathrm{~min}$, incubated in blocking buffer, and then incubated with CD44 rabbit anti-human monoclonal antibody (1:80; Epitomics, Burlingame, CA, USA) at $4^{\circ} \mathrm{C}$ overnight. Cy3-conjugated Affinipure goat polyclonal anti-rabbit immunoglobulin (Ig)G $(\mathrm{H}+\mathrm{L}$; 1:1,000 dilution; Proteintech Group, Wuhan, Hubei, China) was added for an additional 1-h incubation. The cell nuclei were labeled with DAPI (Thermo Fisher Scientific). The coverslips were then mounted on a glass slide and visualized under a laser confocal scanning microscope (LSM710; Zeiss, Oberkochen, Germany).

Western blot analyses. A total of $2 \times 10^{5}$ SGC-7901 cells were seeded in each well of 6 -well plates and incubated for $72 \mathrm{~h}$ with IL-8 (dose identical to adhesion assay). Following stimulation, the cells were collected and denatured by $150 \mu \mathrm{l}$ loading buffer. Proteins in the total cell lysate were separated by SDS-PAGE (10\% separation gel and 5\% spacer gel) and electrotransferred to polyvinylidene difluoride films (Bio-Rad Laboratories, Inc., Hercules, CA, USA). Blotted films were placed in blocking solution for $1 \mathrm{~h}$ at room temperature. CD44 rabbit anti-human monoclonal antibody (1:250, Epitomics) was used to probe the blots overnight at $4^{\circ} \mathrm{C}$. The film was washed thoroughly, incubated with goat polyclonal anti-rabbit IgG horse radish peroxidase secondary antibody (1:1,000; Santa Cruz Biotechnology, Santa Cruz, CA, USA) for $1 \mathrm{~h}$, and then visualized using the enhanced chemiluminescence method (Perkin Elmer Inc., Waltham, MA, USA). Blots were exposed to plain X-ray film in a darkroom. Grayscale reconstruction was performed using Image $\mathrm{J}$ software 1.48 (http://rsb.info.nih.gov./ij/), and the expression rate of CD44 versus that of GAPDH protein, which served as an internal control protein, was calculated. All experiments were repeated three times.

Reverse transcription-quantitative polymerase chain reaction $(R T-q P C R)$ analysis. The SGC-7901 cells $\left(1 \times 10^{5}\right)$ were collected after $72 \mathrm{~h}$ of incubation with IL-8 (dose identical to adhesion assay). Briefly, the total RNA of the cells was extracted using TRIzol reagent (Takara, Shiga, Japan) according to the manufacturer's instructions, and reverse transcribed. RT-qPCR was performed with SYBR Green in a Bio-Rad iQ5 Real-Time PCR system (Bio-Rad Laboratories Inc.). Cycling conditions consisted of one cycle of $95^{\circ} \mathrm{C}$ for $2 \mathrm{~min}, 95^{\circ} \mathrm{C}$ for $15 \mathrm{sec}, 60^{\circ} \mathrm{C}$ for $20 \mathrm{sec}$ and $72^{\circ} \mathrm{C}$ for $20 \mathrm{sec}$, and then $71 \mathrm{cycles}$ of $60-95^{\circ} \mathrm{C}$ for $30 \mathrm{sec}$ (increasing by $0.5^{\circ} \mathrm{C}$ every other cycles). The primer sequences used for amplification are shown in Table I. Based on the $2^{-\Delta \Delta \mathrm{Ct}}$ value, the relative levels of CD44 mRNA expression were 
Table I. Primer sequences used for quantitative polymerase chain reaction.

\begin{tabular}{ll}
\hline mRNA & \multicolumn{1}{c}{ Sense primer sequence } \\
\hline hGAPDH-F & 5'-GGGTGTGAACCATGAGAAGTATG-3' \\
hGAPDH-R & 5'-GATGGCATGGACTGTGGTCAT-3' \\
CD44-F & 5'-ATGGACAAGTTTTGGTGGCA-3' \\
CD44-R & 5'-CAGGTCTCAAATCCGATGCTC-3'
\end{tabular}

F, forward; R, reverse; CD44, cluster of differentiation 44.

Table II. Effect of IL-8 on gastric cancer SGC-7901 cell adhesion and invasion.

\begin{tabular}{lcc}
\hline Concentration, $\mathrm{ng} / \mathrm{ml}$ & Adhesion (OD value) & Invasion (invasive cell number) \\
\hline 0 & $0.186 \pm 0.012$ & $785.00 \pm 48.13$ \\
0.2 & $0.192 \pm 0.018$ & $758.00 \pm 18.04$ \\
0.5 & $0.208 \pm 0.009^{\mathrm{a}}$ & $1115.00 \pm 81.85^{\mathrm{b}}$ \\
0.8 & $0.220 \pm 0.001^{\mathrm{b}, \mathrm{c}}$ & $1041.00 \pm 136.59^{\mathrm{b}}$ \\
1.0 & $0.213 \pm 0.003^{\mathrm{a}, \mathrm{d}}$ & $1103.33 \pm 134.52^{\mathrm{b}}$ \\
\hline
\end{tabular}

${ }^{\mathrm{a}} \mathrm{P}<0.05$ vs. $0 \mathrm{ng} / \mathrm{ml} ;{ }^{b} \mathrm{P}<0.01$ vs. $0 \mathrm{ng} / \mathrm{ml} ;{ }^{\mathrm{C}} \mathrm{P}<0.01$ vs. $0.2 \mathrm{ng} / \mathrm{ml}$; ${ }^{\mathrm{d}} \mathrm{P}<0.05$ vs. $0.2 \mathrm{ng} / \mathrm{ml}$. IL- 8 , interleukin 8 ; OD, optical density.
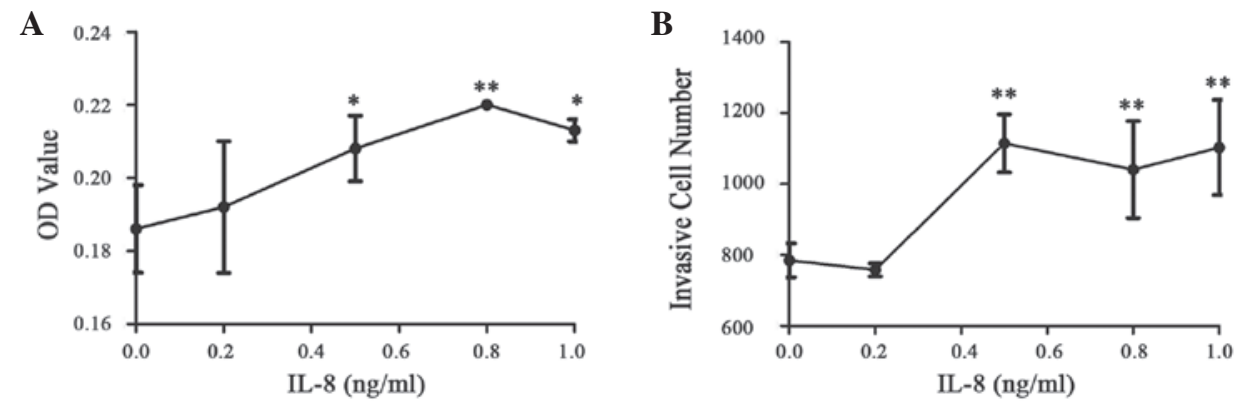

Figure 1. Effect of interleukin (IL)-8 on gastric cancer SGC-7901 cell adhesion and invasion. (A) Cell adhesion was significantly different at various IL-8 concentrations $(\mathrm{P}=0.012)$. Meanwhile, $0.5,0.8$ and $1.0 \mathrm{ng} / \mathrm{ml} \mathrm{IL-8}$ all significantly promoted SGC-7901 cell adhesion compared with $0 \mathrm{ng} / \mathrm{ml} \mathrm{IL-8} \mathrm{(P=0.028,}$ $\mathrm{P}=0.002$ and $\mathrm{P}=0.010$, respectively). The most significant adhesion was found following addition of $0.8 \mathrm{ng} / \mathrm{ml} \mathrm{IL}-8$. However, this effect did not occur in a dose-dependent manner (all P $>0.05$ between the three groups). (B) Similar to the adhesion assay, cell invasion was significantly different at various IL- 8 concentrations $(\mathrm{P}<0.001)$. Moreover, $0.5,0.8$ and $1.0 \mathrm{ng} / \mathrm{ml} \mathrm{IL}-8$ all significantly promoted SGC-7901 cell invasion compared with $0 \mathrm{ng} / \mathrm{ml} \mathrm{IL}-8(\mathrm{P}<0.001$, $\mathrm{P}=0.002$ and $\mathrm{P}<0.001$, respectively), but not in a dose-dependent manner (all $\mathrm{P}>0.05$ between the three groups). ${ }^{*} \mathrm{P}<0.05$ and ${ }^{* *} \mathrm{P}<0.01 \mathrm{vs} .0 \mathrm{ng} / \mathrm{ml} \mathrm{IL}-8$ group. $\mathrm{OD}$, optical density.

calculated. The data were normalized using GADPH as an internal control.

Statistical methods. Statistical analysis was performed using SPSS 13.0 software (SPSS, Inc., Chicago, IL, USA). All results are presented as the mean \pm standard deviation. A one-way analysis of variance was used to assess invasion, adhesion, and protein and mRNA expression levels. The least significant difference method was used to analyze multiple post hoc comparisons. $\mathrm{P} \leq 0.05$ was considered to indicate a statistically significant difference.

\section{Results}

IL-8 promotes SGC-7901 cell adhesion. The present study investigated the effect of low-dose IL- 8 on the adhesion capacity of SGC-7901 cells to fibronectin. The data showed that IL-8 at concentrations of $\geq 0.5 \mathrm{ng} / \mathrm{ml}$ significantly promoted cell adhesion $(\mathrm{P}=0.028, \mathrm{P}=0.002$ and $\mathrm{P}=0.010$ for $0.5,0.8$ and $1.0 \mathrm{ng} / \mathrm{ml}$, respectively). The increase in adhesion peaked at a concentration of $0.8 \mathrm{ng} / \mathrm{ml}$. Notably, this effect was not in a significant dose-dependent manner. No significant differences were identified in adhesion between the groups treated with 0.5 , 0.8 and $1 \mathrm{ng} / \mathrm{ml} \mathrm{IL-8} \mathrm{(P>0.05} \mathrm{between} \mathrm{all} \mathrm{three} \mathrm{groups;} \mathrm{Table} \mathrm{II;}$ Fig. 1A).

IL-8 promotes SGC-7901 cell invasion. The effect of low-dose IL-8 on SGC-7901 cell invasion was also investigated. Similar to the adhesion assay, the invasion of the SGC-7901 cell line was promoted by IL- 8 at concentrations $\geq 0.5 \mathrm{ng} / \mathrm{ml}(\mathrm{P}<0.001$, $\mathrm{P}=0.002$ and $\mathrm{P}<0.001$ for $0.5,0.8$ and $1.0 \mathrm{ng} / \mathrm{ml}$, respectively) and this effect was not in a significant dose-dependent manner. 
Table III. Effect of IL-8 on expression of CD44 protein and mRNA.

\begin{tabular}{llr}
\hline Concentration, $\mathrm{ng} / \mathrm{ml}$ & CD44 protein & CD44 mRNA \\
\hline 0 & $0.899 \pm 0.006$ & $1.00 \pm 0.06$ \\
0.2 & $0.894 \pm 0.001$ & $1.10 \pm 0.11$ \\
0.5 & $0.941 \pm 0.009^{\mathrm{a}, \mathrm{b}}$ & $1.33 \pm 0.12^{\mathrm{c}}$ \\
0.8 & $0.964 \pm 0.005^{\mathrm{a}, \mathrm{b}, \mathrm{d}}$ & $1.40 \pm 0.22^{\mathrm{a}, \mathrm{e}}$ \\
1.0 & $0.911 \pm 0.001^{\mathrm{b}-\mathrm{d}, \mathrm{f}}$ & $1.37 \pm 0.18^{\mathrm{c}, \mathrm{e}}$ \\
\hline
\end{tabular}

${ }^{\mathrm{a}} \mathrm{P}<0.01$ vs. $0 \mathrm{ng} / \mathrm{ml}$; ${ }^{b} \mathrm{P}<0.01$ vs. $0.2 \mathrm{ng} / \mathrm{ml} ;{ }^{\mathrm{c}} \mathrm{P}<0.05 \mathrm{vs} .0 \mathrm{ng} / \mathrm{ml} ;{ }^{\mathrm{d}} \mathrm{P}<0.01 \mathrm{vs} .0 .5 \mathrm{ng} / \mathrm{ml} ;{ }^{\mathrm{e}} \mathrm{P}<0.05 \mathrm{vs} .0 .2 \mathrm{ng} / \mathrm{ml} ;{ }^{\mathrm{f}} \mathrm{P}<0.01 \mathrm{vs} .0 .8 \mathrm{ng} / \mathrm{ml}$. IL-8, interleukin 8; OD, optical density; CD44, cluster of differentiation 44.

A

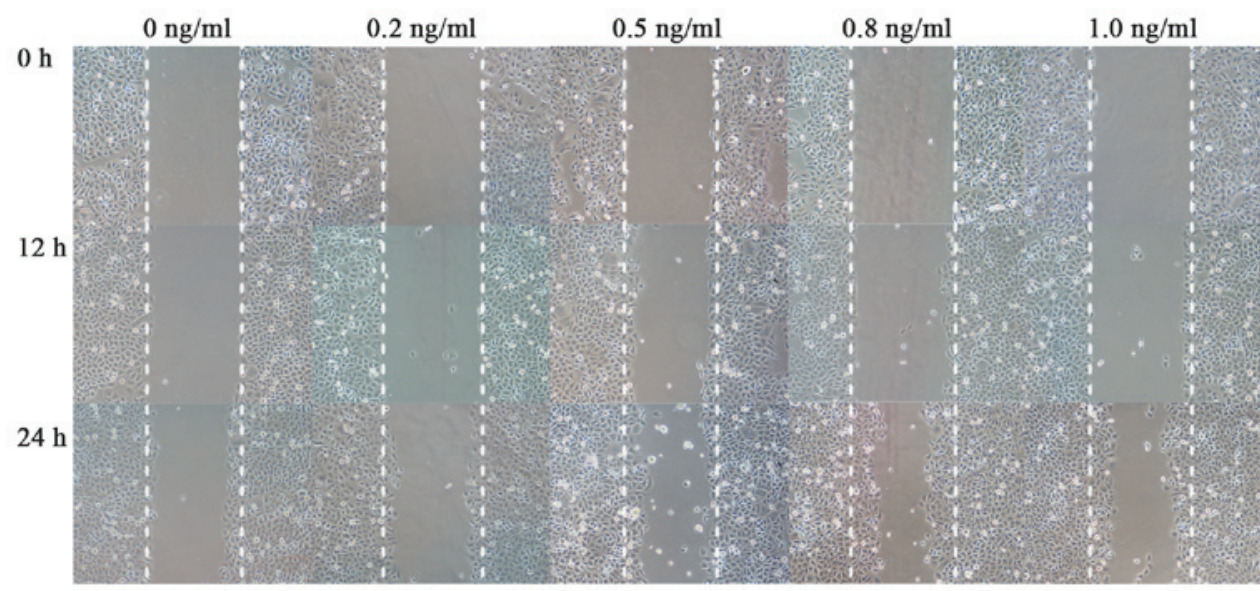

B

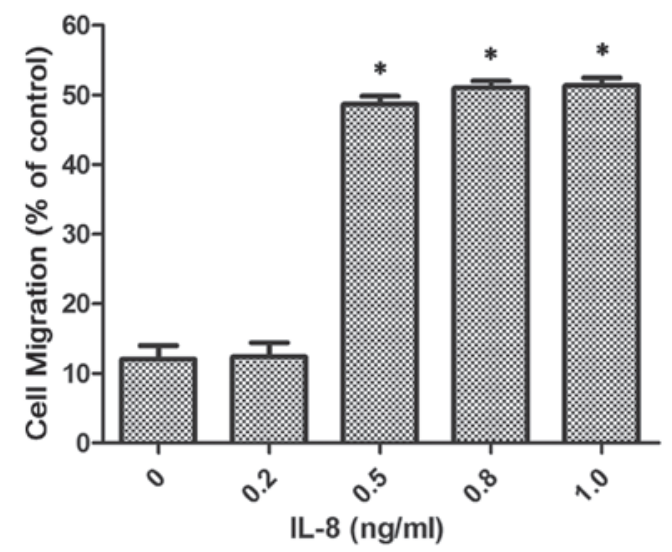

Figure 2. Effect of interleukin (IL-8) on gastric cancer SGC-7901 cell migration (wound scratch assay). (A) Monolayers of SGC-7901 cells exposed to low-dose IL-8 were wounded with pipette tips. The images obtained after $24 \mathrm{~h}$ demonstrated that low-dose IL-8 enhanced the migration capability of the SGC-7901 cells. (B) Quantification of wound healing assay. Treatment with $0.5,0.8$ and $1.0 \mathrm{ng} / \mathrm{ml} \mathrm{IL-8} \mathrm{significantly} \mathrm{promoted} \mathrm{SGC-7901} \mathrm{cell} \mathrm{migration} \mathrm{compared} \mathrm{with}$ the $0 \mathrm{ng} / \mathrm{ml} \mathrm{IL-8} \mathrm{treatment} \mathrm{group}(\mathrm{P}<0.001$ between all three groups), however this effect was not in a significant dose-dependent manner $(\mathrm{P}>0.05$ between all three groups). ${ }^{*} \mathrm{P}<0.001 \mathrm{vs.} 0 \mathrm{ng} / \mathrm{ml} \mathrm{IL}-8$ group.

No significant differences were identified between the groups treated with $0.5,0.8$ and $1 \mathrm{ng} / \mathrm{ml}$ IL- 8 ( $\mathrm{P}>0.05$ between all three groups) (Table II; Fig. 1B).

IL-8 promotes SGC-7901 cell migration. The scratch assay showed IL-8-induced activation of SGC-7901 cell migration. After $24 \mathrm{~h}$, the scratched area recovered more rapidly in IL-8-treated cells compared with untreated cells $(\mathrm{P}<0.001$; Fig. 2). IL-8 significantly promoted the migration of the SGC-7901 cells, however this effect was not in a significant dose-dependent manner. No significant differences were identified between the groups treated with $0.5,0.8$ and $1 \mathrm{ng} /$ ml IL-8 ( $\mathrm{P}>0.05$ between all three groups; Fig. 2).

IL-8 promotes CD44 protein and mRNA levels in SGC-7901 cells. To investigate the possible mechanism of the IL-8-induced adhesion and invasion of gastric cancer cell, the protein and mRNA expression levels of CD44 in SGC-7901 cells exposed to the various low doses of IL- 8 were detected. IL-8 at concentrations of $\geq 0.5 \mathrm{ng} / \mathrm{ml}(0.5,0.8$ and $1.0 \mathrm{ng} / \mathrm{ml})$ 


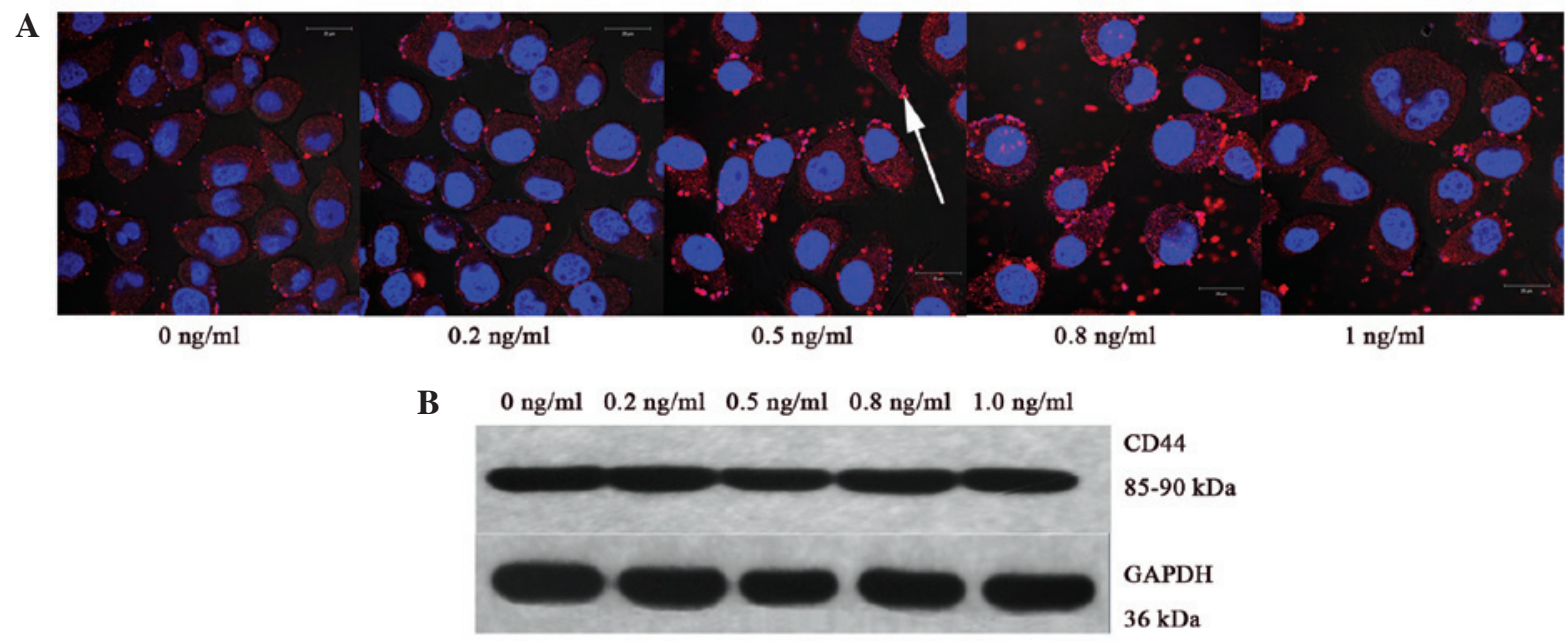

Figure 3. Interleukin (IL)-8 promotes the expression of cluster of differentiation (CD)44 protein in SGC-7901 cells, as determined by immunofluorescence staining and western blotting. (A) Nuclei were marked with DAPI (blue). CD44 immunostaining was restricted to the cell membrane. The white arrowhead points to CD44 counterstained with Cy3 (Red). (B) CD44 protein expression was determined by western blotting. CD44 protein expression was significantly different at various IL-8 concentrations $(\mathrm{P}<0.001)$. Furthermore, $0.5,0.8$ and $1.0 \mathrm{ng} / \mathrm{ml} \mathrm{IL}-8$ all significantly upregulated CD44 protein expression compared with $0 \mathrm{ng} / \mathrm{ml} \mathrm{IL-8}(\mathrm{P}<0.001, \mathrm{P}<0.001$ and $\mathrm{P}=0.018$, respectively) in a dose-dependent manner. The CD44 protein expression level peaked when the cells were exposed to $0.8 \mathrm{ng} / \mathrm{ml} \mathrm{IL}-8$.

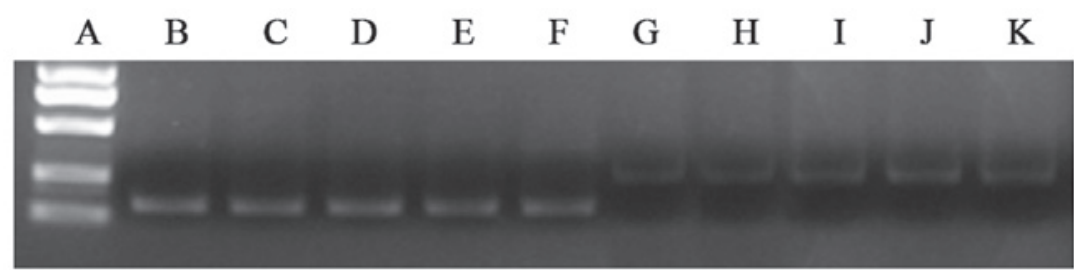

Figure 4. Effect of interleukin (IL)-8 on cluster of differentiation (CD)44 mRNA expression levels in SGC-7901 cells, as determined by reverse transcription-quantitative polymerase chain reaction. (A) Marker DL2000 (from top to bottom: 1000, 750, 500, 250 and 100 bp). (B-F) hGAPDH at (B) 0, (C) 0.2, (D) 0.5 , (E) 0.8 and (F) $1.0 \mathrm{ng} / \mathrm{ml}$ (145 bp). (G-K) CD44 at (G) 0 , (H) 0.2, (I) 0.5 , (J) 0.8 and (K) $1.0 \mathrm{ng} / \mathrm{ml}$ (230 bp). Similar to protein expression, CD44 mRNA expression was significantly different at various IL-8 concentrations $(\mathrm{P}=0.026)$. Moreover, $0.5,0.8$ and $1.0 \mathrm{ng} / \mathrm{ml} \mathrm{IL}-8$ all significantly upregulated CD44 mRNA expression compared with $0 \mathrm{ng} / \mathrm{ml} \mathrm{IL}-8(\mathrm{P}=0.021, \mathrm{P}=0.008$ and $\mathrm{P}=0.012$, respectively), but not in a dose-dependent manner (all $\mathrm{P}>0.05$ between the three groups). The mRNA expression level peaked when the cells were exposed to $0.8 \mathrm{ng} / \mathrm{ml} \mathrm{IL}-8$.

significantly upregulated CD44 protein $(\mathrm{P}<0.001, \mathrm{P}<0.001$ and $\mathrm{P}=0.018)$ and mRNA expression $(\mathrm{P}=0.021, \mathrm{P}=0.008$ and $\mathrm{P}=0.012$ ). Corresponding to the adhesion assay, $\mathrm{CD} 44$ protein and mRNA expression levels peaked following exposure to $0.8 \mathrm{ng} / \mathrm{ml}$ IL-8. A dose-dependent effect was found in CD44 protein expression between the $0.5,0.8$ and $1.0 \mathrm{ng} / \mathrm{ml}$ groups, but not in mRNA expression ( $\mathrm{P}>0.05$ between all three groups; Table III; Figs. 3 and 4).

\section{Discussion}

Metastasis is one of the most fatal characteristics of malignancies, accounting for $>90 \%$ of tumor-related mortalities worldwide (18). Although the incidence of gastric cancer has declined, gastric cancer remains one of the most common malignancies worldwide and frequently develops lymph node, peritoneal and liver metastases (19,20). Distant metastasis is an important sign of a poor prognosis in gastric cancer patients. The metastasis of tumor cells is a complex, multi-staged process that involves tumor cell transformation, growth, angiogenesis, invasion, dissemination and survival in the circulation, followed by adhesion and colonization of a secondary organ or tissue $(18,21)$. Therefore, it has been widely accepted that the capacity of cancer cell adhesion, migration and invasion is one of the most important prerequisites for cancer metastasis (22). IL-8, a multifunctional pro-inflammatory cytokine, has been shown to be associated with infection, inflammation and other disease states, including tumorigenesis $(5,6)$. As an important regulatory autocrine factor within the tumor microenvironment (23), IL-8 is considered to be produced by a range of human cancer cell types, including human melanoma (24), squamous cell carcinoma (25), cervical cancer (26), ovarian cancer (27), non-small cell lung cancer (28) and colon cancer (12), and it mediates potential mitogenic, motogenic and angiogenic effects $(29,30)$. It has been widely accepted that IL-8 plays a significant role in the development and metastasis of cancer (12).

Several studies have found an association between IL-8 and gastric cancer. In one in vitro study, gastric cancer cells produced IL-8 in response to exposure to the cytotoxic strain of Helicobacter pylori, which was classified by WHO as a group I carcinogen (31). IL-8 is involved in the progressive growth of gastric cancer through autocrine or paracrine mechanisms (32). In vivo, IL-8 has been shown to be the most markedly upregulated 
gene in gastric cancer and may regulate the neovascularization of human gastric cancer (33). A significant correlation has bee found between IL-8 levels and the depth of invasion, venous invasion and lymphatic invasion, and IL-8 may be an independent prognostic factor in human gastric carcinoma (34). In a previous study, using treatment of IL- 8 at a concentration of $>1 \mathrm{ng} / \mathrm{ml}$, we reported that IL- 8 could enhance the adhesion, migration and invasion of the human gastric cancer SGC-7901 cell line in a dose-dependent manner (16). This result was supported by another similar study by Kuai et al using cDNA and small interfering RNA transfectants (35). However, IL-8 production by gastric cells is marginal, at even less than $1 \mathrm{ng} / \mathrm{ml}$. For example, the highest level of IL- 8 has been recorded at only $0.17 \mathrm{ng} / \mathrm{ml}$ in IM95 gastric cancer cells cultured for 3 days in vitro (17). It remains unclear whether low-dose IL- 8 also induces the adhesion, migration and invasion of gastric cancer cells in a dose-dependent manner. In the current study, IL-8 ranging from 0.5 to $1 \mathrm{ng} / \mathrm{ml}$ promoted the adhesion, migration and invasion of SGC-7901 gastric cancer cells. Nevertheless, a dose-dependent effect was not found. These results suggested that IL-8 may have potential pro-metastatic effects, even at low doses.

CD44, as a polymorphic integral membrane glycoprotein expressed by a number of cell types, plays a significant role in lymph node homing (36), matrix adhesion (37), and T lymphocyte activation (38). Serving as the main transmembrane hyaluronate receptor, CD44 is regarded not only as a cell adhesion molecule, but also as a determinant of metastatic and invasive behavior in a variety of malignancies, including malignant melanoma, lung carcinoma, breast cancer, leukemia and gastrointestinal carcinomas (39-42).

Metastasis is characterized by a loss of adhesion, and is a significant event in human cancer development that allows cancer cells to leave their original site and subsequently invade and adhere to other sites, for example, the lymph nodes, liver or peritoneum (43). In gastric adenocarcinoma, CD44 is highly expressed and is correlated with a poor prognosis in patients with the intestinal disease type (44). In a previous study, we reported that the regulation of matrix metalloproteinase-9, intercellular adhesion medlecule-1 and E-Cadherin expression may be one of the potential molecule mechanisms for IL-8-induced adhesion, migration and invasion in gastric cancer (16). In the current study, the role of CD44 was further investigated in IL-8-induced adhesion, migration and invasion as another potential molecule mechanism. Similar to the results of the adhesion assay, it was found that CD44 protein and mRNA expression were promoted by low-dose IL- 8 . An increase in the CD44 protein and mRNA expression level was induced most significantly by $0.8 \mathrm{ng} / \mathrm{ml}$ IL-8. This result suggests that the regulation of CD44 expression may be another potential molecule mechanism involved in IL-8-induced adhesion, migration and invasion in gastric cancer.

In conclusion, low-dose IL- 8 may promote the adhesion, migration and invasion of the gastric cancer SGC-7901 cell line, but not in a dose-dependent manner, and that this is correlated with the regulation of CD44 expression.

\section{Acknowledgements}

This study was supported by a grant from the Three-Year Action Plan Fund of Traditional Chinese Medicine, Shanghai City Health Administration (grant no. ZYSNXD-CC-ZDYJ024).

\section{References}

1. Parkin DM, Bray F, Ferlay J and Pisani P: Global cancer statistics, 2002. CA Cancer J Clin 55: 74-108, 2005.

2. Goubran HA, Kotb RR, Stakiw J, Emara ME and Burnouf T: Regulation of tumor growth and metastasis: The role of tumor microenvironment. Cancer Growth Metastasis 7: 9-18, 2014.

3. Araki S, Omori Y, Lyn D, Singh RK, Meinbach DM, Sandman Y, Lokeshwar VB and Lokeshwar BL: Interleukin-8 is a molecular determinant of androgen independence and progression in prostate cancer. Cancer Res 67: 6854-6862, 2007.

4. Waugh DJ and Wilson C: The interleukin-8 pathway in cancer. Clin Cancer Res 14: 6735-6741, 2008.

5. Harada A, Sekido N, Akahoshi T, Wada T, Mukaida N and Matsushima K: Essential involvement of interleukin-8 (IL-8) in acute inflammation. J Leukoc Biol 56: 559-564, 1994.

6. Raman D, Baugher PJ, Thu YM and Richmond A: Role of chemokines in tumor growth. Cancer Lett 256: 137-165, 2007.

7. Xie K: Interleukin-8 and human cancer biology. Cytokine Growth Factor Rev 12: 375-391, 2001.

8. Gabellini C, Trisciuoglio D, Desideri M, Candiloro A, Ragazzoni Y, Orlandi A, Zupi G and Del Bufalo D: Functional activity of CXCL8 receptors, CXCR1 and CXCR2, on human malignant melanoma progression. Eur J Cancer 45: 2618-2627, 2009.

9. Kamohara H, Takahashi M, Ishiko T, Ogawa M and Baba H: Induction of interleukin-8 (CXCL-8) by tumor necrosis factor-alpha and leukemia inhibitory factor in pancreatic carcinoma cells: Impact of CXCL-8 as an autocrine growth factor. Int J Oncol 31: 627-632, 2007.

10. Itoh Y, Joh T, Tanida S, Sasaki M, Kataoka H, Itoh K, Oshima T, Ogasawara N, Togawa S, Wada T, et al: IL-8 promotes cell proliferation and migration through metalloproteinase-cleavage proHB-EGF in human colon carcinoma cells. Cytokine 29: 275-282, 2005

11. Merritt WM, Lin YG, Spannuth WA, Fletcher MS, Kamat AA, Han LY, Landen CN, Jennings N, De Geest K, Langley RR, et al: Effect of interleukin- 8 gene silencing with liposome-encapsulated small interfering RNA on ovarian cancer cell growth. J Natl Cancer Inst 100: 359-372, 2008.

12. Ning Y, Manegold PC, Hong YK, Zhang W, Pohl A, Lurje G, Winder T, Yang D, Labonte MJ, Wilson PM, et al: Interleukin-8 is associated with proliferation, migration, angiogenesis and chemosensitivity in vitro and in vivo in colon cancer cell line models. Int J Cancer 128: 2038-2049, 2011.

13. Matsuo Y, Ochi N, Sawai H, et al: CXCL8/IL-8 and CXCL12/SDF-1alpha co-operatively promote invasiveness and angiogenesis in pancreatic cancer. Int J Cancer 124: 853-861, 2009.

14. Kitadai Y, Takahashi Y, Haruma K, Naka K, Sumii K, Yokozaki H, Yasui W, Mukaida N, Ohmoto Y, Kajiyama G, et al: Transfection of interleukin-8 increases angiogenesis and tumorigenesis of human gastric carcinoma cells in nude mice. Br J Cancer 81: 647-653, 1999.

15. Chen JJ, Yao PL, Yuan A, Hong TM, Shun CT, Kuo ML, Lee YC and Yang PC: Up-regulation of tumor interleukin-8 expression by infiltrating macrophages: Its correlation with tumor angiogenesis and patient survival in non-small cell lung cancer. Clin Cancer Res 9: 729-737, 2003.

16. Ju D, Sun D, Xiu L, Meng X, Zhang C and Wei P: Interleukin-8 is associated with adhesion, migration and invasion in human gastric cancer SCG-7901 cells. Med Oncol 29: 91-99, 2012.

17. Iwai M, Matsuda $M$ and Iwai Y: Cloning of a cancer cell-producing hepatocyte growth factor, vascular endothelial growth factor and interleukin-8 from gastric cancer cells. In Vitro Cell Dev Biol Anim 39: 288-290, 2003.

18. Jin X, Zhu Z and Shi Y: Metastasis mechanism and gene/protein expression in gastric cancer with distant organs metastasis. Bull Cancer, 2014 (Epub ahead of print).

19. Ferlay J, Shin HR, Bray F, Forman D, Mathers C and Parkin DM: Estimates of worldwide burden of cancer in 2008: GLOBOCAN 2008. Int J Cancer. 127: 2893-2917, 2010.

20. Deng JY and Liang H: Clinical significance of lymph node metastasis in gastric cancer. World J Gastroenterol 20: 3967-3975, 2014

21. Goubran HA, Kotb RR, Stakiw J1, Emara ME and Burnouf T: Regulation of tumor growth and metastasis: The role of tumor microenvironment. Cancer Growth Metastasis 7: 9-18, 2014. 
22. Martin TA, Mason MD and Jiang WG: Tight junctions in cancer metastasis. Front Biosci (Landmark Ed) 16: 898-936, 2011.

23. Campbell LM, Maxwell PJ and Waugh DJ: Rationale and means to target pro-inflammatory interleukin-8 (CXCL8) signaling in cancer. Pharmaceuticals (Basel) 6: 929-959, 2013.

24. Gabellini C, Trisciuoglio D, Desideri M, et al: Functional activity of CXCL8 receptors, CXCR1 and CXCR2, on human malignant melanoma progression. Eur J Cancer 45: 2618-2627, 2009.

25. Christofakis EP, Miyazaki H, Rubink DS and Yeudall WA: Roles of CXCL8 in squamous cell carcinoma proliferation and migration. Oral Oncol 44: 920-926, 2008.

26. Wu S, Shang H, Cui L, Zhang Z, Zhang Y, Li Y, Wu J, Li RK and Xie J: Targeted blockade of interleukin-8 abrogates its promotion of cervical cancer growth and metastasis. Mol Cell Biochem 375: 69-79, 2013

27. Wang Y, Xu RC, Zhang XL, Niu XL, Qu Y, Li LZ and Meng XY: Interleukin-8 secretion by ovarian cancer cells increases anchorage-independent growth, proliferation, angiogenic potential, adhesion and invasion. Cytokine 59: 145-155, 2012.

28. Luppi F, Longo AM, de Boer WI, Rabe KF and Hiemstra PS: Interleukin-8 stimulates cell proliferation in non-small cell lung cancer through epidermal growth factor receptor transactivation. Lung Cancer 56: 25-33, 2007.

29. Baggiolini $\mathrm{M}$ and Clark-Lewis I: Interleukin-8, a chemotactic and inflammatory cytokine. FEBS Lett 307: 97-101, 1992

30. Zhu YM and Woll PJ: Mitogenic effects of interleukin-8/CXCL8 on cancer cells. Future Oncol 1: 699-704, 2005.

31. Takagi A, Kamiya S, Koga Y, Ohta U, Kobayashi H, Shirai T, Harasawa S and Miwa T: Analysis of interleukin-8 secretion induced by Helicobacter pylori from the gastric epithelial cell line MKN45: A mechanism independent of the intensity of cytotoxicity. J Gastroenterol Hepatol 12: 368-372, 1997.

32. Kitadai Y, Haruma K, Mukaida N, Ohmoto Y, Matsutani N, Yasui W, Yamamoto S, Sumii K, Kajiyama G, Fidler IJ and Tahara E: Regulation of disease-progression genes in human gastric carcinoma cells by interleukin 8. Clin Cancer Res 6: 2735-2740, 2000.

33. Kitadai Y, Haruma K, Sumii K, Yamamoto S, Ue T, Yokozaki H, Yasui W, Ohmoto Y, Kajiyama G, Fidler IJ and Tahara E: Expression of interleukin-8 correlates with vascularity in human gastric carcinomas. Am J Pathol 152: 93-100, 1998.
34. Kido S, Kitadai Y,Hattori N, Haruma K, Kido T, Ohta M, Tanaka S, Yoshihara M, Sumii K, Ohmoto Y and Chayama K: Interleukin 8 and vascular endothelial growth factor-prognostic factors in human gastric carcinomas? Eur J Cancer 37: 1482-1487, 2001.

35. Kuai WX, Wang Q, Yang XZ, Zhao Y, Yu R and Tang XJ: Interleukin-8 associates with adhesion, migration, invasion and chemosensitivity of human gastric cancer cells. World J Gastroenterol 18: 979-985, 2012.

36. Picker LJ, Nakache M and Butcher EC: Monoclonal antibodies to human lymphocyte homing receptors define a novel class of adhesion molecules on diverse cell types. J Cell Biol 109: 927-937, 1989.

37. Aruffo AI, Stamenkovic I, Melnick M, Underhill CB and Seed B: CD44 is the principal cell surface receptor for hyaluronate. Cell 61: 1303-1313, 1990.

38. Haynes BF, Telen MJ, Hale LP and Denning SM: CD44 - a molecule involved in leukocyte adherence and T-cell activation. Immunol Today 10: 423-428, 1989.

39. Hsieh HF, Yu JC, Ho LI, Chiu SC and Harn HJ: Molecular studies into the role of CD44 variants in metastasis in gastric cancer. Mol Pathol 52: 25-28, 1999.

40. Abbaszadegan MR, Moaven O, Sima HR, Ghafarzadegan K, A'rabi A, Forghani MN, Raziee HR, Mashhadinejad A, Jafarzadeh M,Esmaili-Shandiz E and Dadkhah E: p16 promoter hypermethylation: A useful serum marker for early detection of gastric cancer. World J Gastroenterol 14: 2055-2060, 2008.

41. Zavrides HN, Zizi-Sermpetzoglou A, Panousopoulos D, Athanasas G, Elemenoglou I and Peros G: Prognostic evaluation of CD44 expression in correlation with bcl-2 and p53 in colorectal cancer. Folia Histochem Cytobiol 43: 31-36, 2005.

42. Wang DR, Chen GY, Liu XL, Miao Y, Xia JG, Zhu LH and Tang D: CD44v6 in peripheral blood and bone marrow of patients with gastric cancer as micro-metastasis. World J Gastroenterol 12: 36-42, 2006.

43. Jothy S: CD44 and its partners in metastasis. Clin Exp Metastasis 20: 195-201, 2003.

44. Ghaffarzadehgan K, Jafarzadeh M, Raziee HR, Sima HR, Esmaili-Shandiz E, Hosseinnezhad H, Taghizadeh-Kermani A, Moaven $\mathrm{O}$ and Bahrani M: Expression of cell adhesion molecule CD44 in gastric adenocarcinoma and its prognostic importance. World J Gastroenterol 14: 6376-6381, 2008. 